probable therefore that the flood waters which irrigate Egypt originate in the Atlantic. The small contribution which the rain of the Lake Plateau makes to the Nile flow is put at about 16 per cent of the total flow. The Blue Nile is the great feeder, but the importance for this river of Lake Tana has been exaggerated; other tributaries are more important than the one draining Tana. The waters of the White Nile are dammed up by those of the Blue Nile when the latter is in flood, and much of the White Nile waters then, as at other times also, is lost by evaporation.

Dr. Hurst concludes with some suggestions for improving control of the river. The amount of water lost by evaporation in the Bahr-el-Jebel swamps is enormous. Possible ways of preventing this loss are either by the embankment of the Jebel and the Zeraf to prevent the spilling of water into the marshes, or the construction of a new straight channel outside the swamps into which the flow could be diverted. The loss of water on the Bahr-el-Ghazal Basin also calls for preventive measures. There is also the problem of constructing a dam below Lake Albert in order to use that lake as a storage reservoir. Another among the schemes touched on is the proposal for a power-station at the Aswan Barrage.

\section{PROCEEDINGS OF THE ZOOLOGICAL SOCIETY OF LONDON}

$\mathbf{N}$ the current number of the Proceedings of the Zoological Society, comprising Parts 1 and 2 of Volume 114, the division into two series (A and B) has been discontinued. Accordingly, all papers will now be published in a single annual volume, containing four parts. The issue of the Proceedings in three series, (A) General and Experimental, (B) Systematic and Morphological, and (C) Abstracts of papers communicated at the scientific meetings, was introduced in 1937, and at the same time the practice of giving a serial number to each volume. Previously the volumes were referred to only by the year of issue, which occasionally introduced some uncertainty about the date of publication, since the last part of the volume for any particular year might not appear until January or February in the following year. A further complication arises as a result of the large number of pages contained in the Proceedings of some particular years, which necessitated their being bound in two volumes, and title pages and contents sheets were supplied for this purpose. It thus became necessary to refer to the first or second 'volume' of each year of issue. The use of a serial volume number, which will be printed on all future parts, will obviate this necessity, and simplify bibliographic references to publications in the Proceedings.

The present number comprises ten papers dealing with a wide variety of subjects. F. W. Rogers Brambell has a paper on the reproduction of the wild rabbit, Oryctolagus cuniculus (L.), based on the examination of 957 males, 1,529 females and 1 inter-sex, obtained in Caernarvonshire between February 1941 and June 1942. A very interesting problem arises in connexion with the pre-natal mortality. It is estimated that at least 60 per cent of litters conceived are lost owing to the death and reabsorption of all the embryos, the majority of which die on or about the twelfth day. The mean number of young born to each adult female is found to be between
$10 \cdot 35$ and $11 \cdot 70$ per annum. Ti-Chow Tung and $\mathrm{Yu}$ Fung-Yeh Tung give an account of experiments supporting their view that in the goldfish, Carassius auratus, there exists some centre comparable to the amphibian grey crescent from which the organizer region later arises. R. I. Pocock discusses the races of the North African wild cat. E. J. Popham describes the changes in an aquatic insect population produced by using minnows as predators. A significant difference between the population of three Corixids collected each week was observed, and after the introduction of the minnows the relative proportions of Corixids adapted to the background increased. Robert Gurney deals with the systematics of the crustacean genus Callianassa, and G. H. Findlay describes the development of the auditory ossicles in the elephant shrew, the tenrec and the golden mole. G. P. Wells has a paper emphasizing the inadequacy of our knowledge of even the commonest laboratory animals. The neuropodia and notopodia of Arenicola marina, L., are described in detail, and for working out the anatorny of the intricate musculature the use of polarized light is recommended. L. S. Ramaswami gives an account of the heart and associated vessels in some genera of Apoda, and V. V. Tchernavin gives a revision of the subfamily Orestiinæ and a revision of some Trichomycterinæ, including descriptions of new species based on material preserved in the British Museum, a great part of which was collected by the Titicaca Expedition, of the species of these little-known groups of freshwater fishes.

\section{RUSTY WATER AND MOSQUITO BREEDING}

$\mathrm{W}$ E have received a report by $\mathrm{Mr}$. K. B. Williamson, malaria research officer, Penang (c/o Ross Institute of Tropical Hygiene, London School of Hygiene and Tropical Medicine, W.C.1), on an "Investigation of Ferruginous Waters in relation to the Breeding of Malaria-carrying Mosquitoes". It is a common observation among malariologists in the tropics that waters containing rusty deposits or bearing iridescent surface films of precipitated iron are generally free from mosquito larvæ, and the possibility of utilizing this fact for the control of mosquito breeding has often been mooted. But exact information about the composition of waters of this kind and about the source of the iron has been wanting. Mr. Williamson's report is based on the examination of various types of rusty waters on Hampstead Heath and elsewhere in the neighbourhood of London and around Malvern, as well as upon his experiences in Malaya. It deals mainly with questions of chemistry.

Iron occurs in water: (1) in particulate form as colloidal ferric hydroxide ('iron rust'), the particles being so small that the water is quite clear; it is this colloidal iron which is unstable and readily gives rise to solid aggregates in the form of surface films or precipitates; $(2)$ in true solution as ionized salts of ferrous or ferric iron; (3) as non-ionized organic complexes.

The humic matter derived from the slow rotting of excess vegetation present in soil combines with both ferrous and ferric iron and exerts a stabilizing influence on the colloidal ferric oxide. Humic matter is itself antagonistic to the breeding of most species. 
of malaria-carrying mosquitoes. Excess of rotting vegetation in contact with the soil will thus exert a dual benefit.

A provisional attempt has been made to classify ferruginous waters. A ferruginous water is defined as one that contains a minimum of two parts per million of iron in solution or colloidal suspension. Many so-called 'rusty' waters show merely a deposit of rust-coloured sediment which has been thrown down at an earlier date; a deposit of this kind affords no proof that the water continues supercharged with iron. On the other hand, superficial films of 'rust' supply a more immediate indication of the presence of an unstable excess of iron in water. Such iron may be derived (i) from underground mineral sources such as pyrites, (ii) from vegetation rotted under anaerobic conditions in marshy soil, the iron-containing humus forming organic complexes with the iron present in the superficial soil, or (iii) in small amount, from the rotting of vegetation alone in the water.

On the biological side the work is incomplete. Observations on the natural fauna and flora of ferruginous waters have been rather limited; but such waters are characterized by an almost complete absence of water insects, aquatic helminths, Crustacea and Algæ. It has been found by experiment that mosquito larvæ (Anopheles maculipennis var. atroparvus), newly hatched from the egg, are unaffected by the iron-containing waters provided they are fed; but when placed in samples of such waters without added food they soon die of starvation. It is, therefore, concluded that mosquito larvæ fail to develop in rusty water from lack of food, which is ascribed in the main to the inimical effects of colloidal iron upon the growth of Algæ, Protozoa and other microorganisms. There is no evidence that iron-containing surface films will suffocate the larvæ.

\section{FUEL RESEARCH}

$\mathrm{T}$ HE Melchett Lecture for 1944 of the Institute of Fuel was delivered on October 12 by Dr. J. G. King on the "Pattern of Fuel Research". Under this title he gave an account of the progress of fuel research seen as a whole, with main branches and subsections fitting together into patterns although the work may have been done in many places, by various organizations and individuals.

The three main patterns chosen were the hydrogenation, the gasification and the study of the constitution and properties of coal. Dr. King gave a survey of the development, from the first observations of Bergius in 1912, of the hydrogenation of solid coal, of the liquid products of carbonization and of petroleum. Actually the conversion of solid coal to liquid fuels ranging from heavy oil to light spirits and hydrocarbon gases involves an interwoven sequence of stages. Behind the large-scale operations now in use stands an immense volume of patient experiment to fix the choice of catalysts, temperature. pressure and other conditions necessary for success, some of which has been done at the Fuel Research Station under Dr. King's direction.

The carbonization of coal in ovens or retorts carries the limitation that only about one fourth of the raw coal can be recovered in the gaseous form. By gasification in the gas producer, it is possible to recover nearly all the fuel in a fluid form but unsuitable for public supply. It came to be recognized that by substituting oxygen for air and working at pressures above atmospheric, the products of gasification could be modified in chemical composition to give a product more suited for public distribution. It happens that in our generation, the technique of oxygen production has so developed as to make it possible to use oxygen in fuel manufacture -at least in some countries. In Great Britain the Joint Research Committee of the Institution of Gas Engineers and the University of Leeds has pursued the problems involved for nearly ten years. It is found that a range of technique is possible, from direct hydrogenation of coal to methane, reaching to a synthesis of methane from the product of pre-gasification of coke by oxygen and steam. These investigations are now in the stage of large-scale operation. In the long run, the successful achievement of this part of the pattern of fuel research can have far-reaching effects.

Dr. King's third main branch of the pattern covers the study of coal constitution and properties both physical and chemical. This includes the immense volume of work done in laboratories all over the world. It would appear that the results of this work, though marked often by ingenuity and industry, have been, in the main, of academic value only, and no clear pattern is revealed. It is thus unlike the first two branches, which concern themselves with the developments of processes. The study of constitution and properties must, however, be of assistance to them.

Dr. King's lecture ean be commended as an excellent picture of the pattern of current research on fuel.

\section{FORTHCOMING EVENTS}

\section{Saturday, December 2}

INSTITUTE OF PHYSICS (LONDON AND HOME COENTIES' BRANCH) (at the Royal Institution, Albemarle Street, London, W.1), at 2 p.m. -Conference on "The Selection and Training of Personnel fo Industry" (to be opened by Major F. A. Freeth, F.R.S.).

GEOLOGIST's' Association (at the Geological Society of London, Burlington House, Piccadilly, London, W.1), at 2.30 p.m.--Dr. G. M. Lees: "The Geology of the Oilfields of the Middle East".

SHEFFIELD METALECRGMCAL ASSOCTATION (joint meeting with the IRON AND STEEL INSTITTTE and the SHEFFIELD SOCIETY OF ENGINEERS AND METALLURGISTS) (at the Royal Victoria Station Hotel, Sheffield) at 2.30 p.m.

\section{Monday, December 4}

ROYAL SOCTETY OF ARTS (at John Adam Street, Adelphi, London, W.C.2), at 1.45 p.m.-Dr. S. K. Kon: "Milk", (3) "Mfilk in relation to Human Nutrition-Recent Aspects" (Cantor Lecture).

FARYERS' CLUB (at the Royal Empire Society, Craven Street, Strand, London, W.C.2), at 2.30 p.m.-Mr. H. R. Davidson: "Pigs in the Long Range Policy".

ROYAL GEOGRA PHICAL SOCTETX (at Kensington Gore, South Kensington, London, S.W.7), at 5 p.m.--Dr. J. K. St. Joseph: "Air Photography in Archæology".

SOCIETY OF ENGINEERS (at the Geological Society Burlington House, Piccadilly, Iondon, W.1), at 5 p.m.-Mr. E. S. Waddington : Welding".

\section{Tuesday, December 5}

RoYal ANTHRopological INSTriteg (at the Royal Geographical Society, Kensington Gore, London, S.W.7), at 1.30 p.m.-Mrs. Olive Murray Chapman: "A Journey across Madagascar".

BRIRISH SOCIETY FOR INTERNATIONAT BIBLIOGRAPHY (at the Institution of Electrical Ingineers, Savoy Place, Victoria Embank-
ment, London, W.C.2), at 2.30 p.m.-Mr. W. C. Cooper: "The ment, London, W.C.2), at 2.30 p.m.-Mr. W. C. Cooper : "The Dr. J. A. Wilcken : "Abstracting, Indexing and Classification". RoYAt LNsTremion (at 21 Albemarle Street, Piccadilly, London, W.1), at 5.15 p.m.- Sir Henry Dale, O.M., G.B.E.,Pres.R.S.: "Modern Developments in Chemical Therapeutics", (i) "Beginnings of Chemotherapy".

INSTITUTION OF CIVIL ENGINEERS (STRUOTURAL AND BUILDING FingINGERING Drvision) (at Great George Street, Westminster, Lon-
don, S.W.1), at 5.30 p.m.- - Prof. A. J. Sutton Pippard and Letitia Chitty: "Some Problems presented by Cable Bracing".

QUEkETT Microscopical Soctert (at the Royal Society, Burling. ton House, Piccadilly, London, W.1), at 7 p.m.-Exhibits. 